The Uganda-Congo Boundary Commission: Summary Report

Author(s): R. G. T. Bright

Source: The Geographical Journal, Vol. 32, No. 5 (Nov., 1908), pp. 488-493

Published by: geographicalj

Stable URL: http://www.jstor.org/stable/1777167

Accessed: 27-06-2016 02:34 UTC

Your use of the JSTOR archive indicates your acceptance of the Terms \& Conditions of Use, available at

http://about.jstor.org/terms

JSTOR is a not-for-profit service that helps scholars, researchers, and students discover, use, and build upon a wide range of content in a trusted digital archive. We use information technology and tools to increase productivity and facilitate new forms of scholarship. For more information about JSTOR, please contact support@jstor.org.

The Royal Geographical Society (with the Institute of British Geographers), Wiley are collaborating with JSTOR to digitize, preserve and extend access to The Geographical Journal 
In Skyring and Otway various important plants reach their southern limit, as, e.g., Pseudopanax lcetevirens, Tepualia stipularis, Gunnera chilensis (the famous giant "pangue"), and Dacrydium Jonkii.

Of a certain importance was the survey of the vegetation in the vicinity of the great glaciers. Close to the ice grows quite a number of alpine plants, at the very sea-level, and the first arboreous vegetation is represented by Nothofagus antarctica, the same species that constitutes the forest at its vertical limit on the mountain-slopes.

That the peculiar conditions in Skyring water should act upon the constitution of the marine flora, seems quite natural. Already in Otway one notes a certain poverty in species, but the flora there is rich in comparison with that of Skyring. As there are practically no tides, the littoral flora is exceedingly poor. And the freshness of the water has made the sublittoral Macrocystis formation disappear, an association that otherwise never seems to lack round subantarctic shores. The most common aquatic plant in Skyring is a Ruppia, forming extensive submarine meadows.

In Fitzroy channel, as well as in Gajàrdo channel, the typical algæ reappear, the Corallinaceæ again cover the stones, and the great kelp floats along on the surface.

Zoology.-The influence of the brackish water in Skyring upon the fauna is easy to recognize. Almost all the characteristic and common Magellanic creatures have disappeared. But one need not go farther than the Fitzroy channel, and the dredge will bring up a rich harvest.

\section{THE UGANDA-CONGO BOUNDARY COMMISSION.*}

\section{Summary Report.}

By Major R. G. T. BRIGHT, C.M.G.

During the work of the British Section of the recent Anglo-Congolese Boundury Commission for the survey of the country on the western border of the Uganda Protectorate, a survey was completed of the country in the vicinity of the 30th meridian east of Greenwich from lat. S. $1^{\circ}$, and extending westwards to the river Ruchuro, to nearly the second parallel of north latitude. The eastern shore of Lake Albert Edward and the whole of its north-easterly arm, called on maps Lake Ruisamba or Dweru, was mapped. The river Semliki was fullowed throughout its course from Lake Albert Edward to Lake Albert. All the eastern shore of the latter up to the Victoria Nile was surveyed, and a great portion also of its opposite side.

* At one of the meetings during the new session Major Bright will give a full account of the results of this expedition, which will be accompanied by a map. 
As much as possible was done to delineate the features of Mount Ruwenzori, and it may be said that it was mapped up to its snow-line. Higher than that it was not considered necessary to go, nor would it have been practicable to survey in the snow-covered regions without special equipment. But little of the country passed through can be said to be absolutely unknown. Various explorers have travelled through it and made maps, though but only two can be said to have done really accurate surveys, and these are His Royal Highness the Duke of the Abruzzi on Ruwenzori and Captain T. T. Behrens, Royal Engineers, who, during the Anglo-German Boundary Commission in Uganda, made a map of the eastern shore of Lake Albert Edward. The results obtained by the recent Boundary Commission agreed very closely with those obtained by these gentlemen.

The principal physical features of the country traversed by the commission, in addition to those previously mentioned, are the highlands of the western part of Ankoli, the arm of the great Ituri forest in the Semliki valley, the Bulegga uplands on the Nile-Congo watershed, the escarpment bordering the eastern shore of Lake Albert, and the Victoria Nile. Extending from a little north of lat. S. $1^{\circ}$ to as far as can be seen southwards, is a wild mountainous country, the peaks of which range from 6000 to 8000 feet above mean sea-level. North of this region, though still keeping a highland character, it is open and less wooded. The soil appears to be rich and productive, and the climate is cool and healthy. It is here chiefly a pasture country, inhabited by Bahima.

The two lakes Albert Edward and Albert are very similar in surroundings and character. Each has the appearance of a shallow lake, occupying a portion of what must once have been its bed. In Chaangu, on the west of Lake Albert Edward, rises a range of mountains reaching over 8000 feet in beight. The Semliki flows out of the north end of Lake Albert Edward, and is throughout its course a fine broad river varying from 60 to 100 yards in width. It is broken in places by cataracts and rapids. Its total fall is about 960 feet in its length of 155 miles, from 3000 feet, the height of Albert Edward, to 2037 feet, the level of Lake Albert. The eastern extremity of the great equatorial forest is often of the greatest density, though not always tropical in character. It extends unbroken from the higher slopes of Ruwenzori across the Semliki valley, and away to the west.

Lying between the Semliki valley and the plateau to the north of the Lake Albert Edward depression is the long ridge of Ruwenzori. The snow-peaks of Ruwenzori, which form such a striking and curious feature in close proximity to the equator, are comprised in an area of some 55 square miles in the central part of the mountain. They consist of three main groups or " massifs." North of these are two smaller peaks, and south is a chain of lower heights. The height obtained for 
the summit was 16,794 feet, former heights being by H.R.H. The Duke of the Abruzzi, 16,815 feet, and by Captain Behrens, 16,618 feet. The snow-line in the valleys comes as low as 13,200 feet, but on the peaks it appears to be higher. No peak was observed of a less altitude than 14,700 feet that had snow on it, except occasionally and temporarily.

On the west of Lake Albert, the mountains, which rise to an altitude of 7000 feet and over, fall sheer into the water along its whole extent, save at the south end, where there is a plain between the lake and the hills. On the east of the lake is a similar steep escarpment, commencing from the northern slopes of Ruwenzori, and rising abruptly from the flat Semliki plains; this gradually diminishes, and, eventually leaving the Albert, terminates near the Victoria Nile.

On the west of the Semliki valley is the Nile-Congo watershed. Hills rise, forest-clad up to Mboga; north of that settlement, they become open grassland and are known as the Bulegga hills. This is a cool and pleasant district, fertile and inhabited by cattle-owning natives. From where the watershed approaches the lake (and it is within a few miles of it), it becomes, in that part which lies within the Uganda Protectorate, thinly populated and diffisult for travelling.

But few portions of the country which was seen by the commission were uninhabited. In the southern regions (Ankoli) the population can be roughly classified as the Bahima, the aristocracy, and the Bæro, the cultivators and serfs. When the Galla invaders came down from the north they established a powerful branch of the Hamitic family in Ankoli. The Bæro, on the contrary, are a distinctly Bantu race. The fact that for years they have supplied the Bahima nobles with concubines has done much to spread the Galla blood, but still there can be no doubt that the Bæro are a negroid and inferior people. The billy country to the south of Lake Albert Edward is tenanted by the Basiggi or Bachigga. This tribe is of Bæro stock, but of a lower degree of civilization. They have no chiefs, but manage their affairs by families. A sect of witch doctresses, which calls itself Niawingi, has obtained great influence in the more remote districts. This power is unfortunately hostile to European influence, and is mainly used to stir up strife.

The Semliki forest is inhabited by the Baamba, a Bantu race. This tribe is addicted to cannibalism, and constant warfare goes on between village and village. The Baamba, however, greatly fear the pygmies who live noar them. These little people prey on the crops of their larger neighbours, but in return do them service when fighting or hunting. The Batwa or Bambutu inhabit the forest. They stand about 4 feet high, and are long-armed, short-legged, and ugly, being usually distinctly prognathous. They have no religion and no industries. No attempt is made to cultivate, but they depend entirely on game and what they can steal from their neighbours. The Banande appear to be related to the pygmies, but not of them. They are bigger and more 
Simian in appearance. It seems that they are absolute pariahs, and are found hanging around the Baamba or Bavira villages, literally living on what they can pick up.

In the country between the Nile-Congo watershed and Lake Albert the inhabitants differ widely. The Balegga and Bavira are closely allied. Their physique is finer than the natives of either Ankoli or Toro; they belong to the Bantu race. Except that these natires occasionally spear or shoot a man, belonging to some other chief, with an arrow, they are a friendly and pleasant people. Their neighbours, the Lendu, are Nilotic. They are warlike, and are continually fighting with each other or any one else they think themselves strong enough to overcome. There is little intercourse between the Lendu and Balegga.

Generally speaking, the country passed is occupied by a mass of granite and gneiss and a series of crystalline rocks of indeterminate age, overlain in the sunken areas of Lake Albert Edward and the Semliki valley and in the depression containing the north-east extension of Lake Albert Edward by alluvium, and in four small detached districts by volcanic rocks. The high plateau to the east of Lake Albert Edward and Ruwenzori consists mainly of gneiss, with intercalations of schistose rocks of various kinds and bands of quartzite. The Bulegga plateau is a mass of granite, intersected by numerous basic dykes, and bordered on the south-east by a zone of gneissose and schistose rocks, with some accompanying fault-breccias, which afford evidence of the faulting and subsidence which have occurred there. The foothills of Ruwenzori consist similarly of quartzite, quartzose schists, sheared quartz-felspar rocks, and gneiss of various types, with intercalations of epidiorite and amphibolite schist, all dipping vertically and striking generally in the direction of the range. Volcanic rocks occur in the four districts of Kichwamba, Katwe, Kyatwa, and Fort Portal. A large quantity of salt is extracted by the natives from the Katwe salt lake. The salt seems to be derived from certain bands of tuff by percolating surface water, which rises as springs in the bed of the lake.

The open plains to the south of Lake Albert Edward were covered with game. Uganda cob ( $C$. Thomasi) were found in great numbera. The river Ruchuro swarms with hippopotamuses, which are left severely alone by the natives, though in the river they might be attacked with little or no danger. A curious feature of the Albert Edward is the great number of dead fish that are found floating on the surface. The natives say that they die from bad water. This lake is usually supposed to be quite free from crocodiles. The country between the Congolese stations Kasindi and Beni is an ideal elephant country, and is tenanted by some large herds. In the thick forest west of the Semliki valley elephant and buffalo were plentiful, but, excepting parrots, there was very little bird-life. On the Congo-Nile watershed in the neighbourhood of Lake Albert there is practically no animal-life. A small herd 
of red Congo buffalo (Bos Caffer Nanus) was seen in the Semliki forest.

Throughout the commission, with the exception of the north-easterly shore of Lake Albert, no cases of sleeping sickness were seen. Unfortunately, this is no guarantee that the country will continue free from the disease. Tsetse-fly belts are common along the lake-shores, wherever bush comes near the water's edge and spreads up the banks of the streanis flowing into the lakes.

The staff of the British section were: Major (temporary Lieut.Colonel) R. G. T. Bright, c.м.G., Rifle Brigade; Captain E. M. Jack, R.E. ; Captain the Honble. F. Prittie, Rifle Brigade; Mr. C. Chevallier; and Captain A. MacGregor and Captain S. Iredell of the King's African Rifles, Mr. J. Coates, and Mr. G. McCaw, and four British non-commissioned officers.

The commission started triangulation from two points fixed by the Anglo-German Boundary Commission (Uganda). These positions were obtained by a continuous triangulation from Zanzibar, the longitude of that place having been determined by telegraph some years previously. In the British calculations Clarke's figure of the Earth was used. The main triangulation on the east followed generally the line of the 30 th meridian, on the west it extended to the river Ruchuro and the east shore of Lake Albert Edward. It was extended eastward to include the north-east branch of that lake, and from there passed northwards round and across the northern slopes of Ruwenzori. From the neighbourhood of the northern shore of Lake Albert Edward, the triangulation was extended to the west of Ruwenzori, and closed with a point of the eastern triangulation on the northern spur. North of this junction it was continued to the Congo-Nile watershed; then north-eastwards along the western shore of Lake Albert nearly as far as lat. N. $2^{\circ}$. A rapid triangulation, connected with the main triangulation, was carried along the eastern shore of Lake Albert to the vicinity of the Victoria Nile.

During the work of the commission a scheme was prepared for the geodetic measurement of the 30 th meridian, and when the actual survey of the boundary zone was completed, the measurement of the arc was commenced. The topography was carried out on the scale of $1: 250,000$. Plane-tables were used throughout, with Indian pattern clinometers, except in the dense forest, where traverses between fixed points were made with the prismatic compass. Over twenty prominent peaks of Ruwenzori were fixed trigonometrically, including eleven above the snow-line. Of these eight were previously mapped by H.R.H. The Duke of the Abruzzi, and the positions agreed closely with his. Two check-bases were measured. The Invar-Jäderin apparatus was used, this having been brought out for subsequent use on geodetic work. At two positions astronomical observations were also taken for latitude and azimuth. The results, though quite discordant with the triangulation 
latitudes, are of scientific interest. The large mass of Ruwenzori is the cause of the local attraction, and is probably enough to account for the differences.

\section{LEVELLING BETWEEN THE NILE AND CONGO BASINS.*}

As was pointed out by Captain Behrens in his paper printed in the Journal for March, 1907, precise data for a knowledge of the altitudes of the lakes and other surface features of Equatorial Africa have been gradually accumulating within recent years, thanks to the careful observations carried out by various boundary or railway surveys. Some addition to our knowledge in this respect has been made by the surveys undertaken on behalf of the Congo State along the lines of projected railways in the region between the upper Nile and the Congo, Through the courtesy of M. Liebrechts, Secrétaire-Général du Départment de l'Intérieur du Congo, copies of the maps showing the results of these surveys have been forwarded to us through Captain S. F. Newcombe, R.E., an officer in the service of the Sudan Government, who has accompanied them with some explanatory notes. The map given with the present number is a reduction from the Belgian maps.

It will be seen that three different lines of levels are included. The first of these, shown in the lower part of the sheet in sects. I.-III., runs along the western bank of the Nile from Dufile to Rejaf, connecting the navigable portions of the river above and below the rapids. The sheets of the Belgian map were plotted on the scale of $1: 20,000$, but this has been reduced in our map to that of $1: 250,000$. 'The two other lines are those from Stanleyville on the Congo to the Albert Nyanza via the upper Ituri, and from Tanganyik a to the upper Ituri, connecting with the first. They are shown together on the main portion of the sheet, on the scale of $1: 2,000,000$, or half of that on which the original surveys were combined in the Belgian map sent to us. A note on this last explains that the separate sections were constructed on different magnetic meridians, but that in the absence of definite information as to the amount of declination in each case, the original orientation of each has been retained. In preparing the accompanying map the draughtsman has, however, adapted the separate sections of the traverse to positions taken from the best existing maps.

In the Belgian survey between the Congo and the Albert Nyanza the altitudes were referred to the starting-point at Stanleyville as a base. The altitude of this has been fixed instrumentally from the West Coast as 430 metres, or 1351 feet, and on this basis the altitude of the Albert lake is given by the Belgian survey as 639 metres, or 2096 feet. This figure differs by 59 feet from that adopted at the

$$
\text { * Map, p. } 548 .
$$

